Walter de Gruyter Publishers

1749-1999

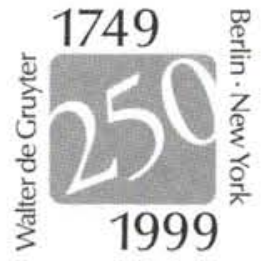





\section{Anne-Katrin Ziesak}

\section{Walter de Gruyter Publishers$$
\text { 1749-1999 }
$$

With contributions by

Hans-Robert Cram, Kurt-Georg Cram

and Andreas Terwey

Translated by

Rhodes Barrett

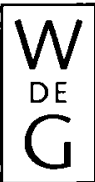

Walter de Gruyter - Berlin - New York

1999 
Published on the occasion of the exhibition

Der Verlag Walter de Gruyter · 1749-1999

at the Staatsbibliothek zu Berlin, Haus Unter den Linden

September 30-November 20, 1999

Responsible for the exhibition

in collaboration with the Staatsbibliothek

Evelyne Glowka

Exhibition Director

Anne-Katrin Ziesak

Scenography

Rainer Lendler

Restoration

Staatsbibliothek zu Berlin

(0) Printed on acid-free paper which falls within the guidelines of the ANSI to ensure permanence and durability.

Die Deutsche Bibliothek - Cataloging-in-Publication-Data

Walter de Gruyter Publishers: 1749-1999 ; [on occasion of the Exhibition Der Verlag Walter de Gruyter, 1749-1999 at the Staatsbibliothek zu Berlin, Haus Unter den Linden, September 30-November 20, 1999] / AnneKatrin Ziesak. With contributions by Hans-Robert Cram ... Transl. by Rhodes Barrett. - Berlin ; New York : de Gruyter, 1999

Dt. Ausg. u.d.T.: Der Verlag Walter de Gruyter

ISBN 3-11-016699-2 Gb.

ISBN 3-11-016741-7 Pb.

(C) Copyright 1999 by Walter de Gruyter GmbH \& Co. KG, D-10785 Berlin

All rights reserved, including those of translation into foreign languages. No part of this book may be reproduced or transmitted in any form or by any means, electronic or mechanical, including photocopy, recording, or any information storage and retrieval system, without permission in writing from the publisher.

Printed in Germany

Cover design: Christopher Schneider, Berlin - Disk conversion and typesetting: Arthur Collignon GmbH, Berlin - Reprographics: Laserline, Berlin - Printing: H. Heenemann GmbH \& Co, Berlin - Binding: Lüderitz \& Bauer-GmbH, Berlin 